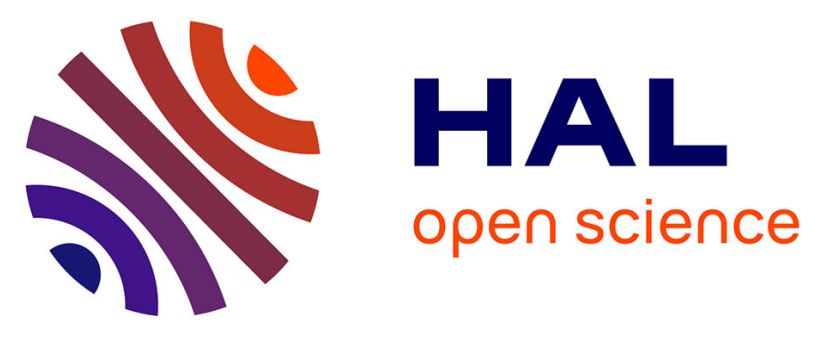

\title{
Low Frequency of Cytomegalovirus Infection during Exacerbations of Inflammatory Bowel Diseases.
}

Nicolas Lévêque, Hédia Brixi-Benmansour, Thierry Reig, Fanny Renois, Déborah Talmud, Véronique Brodard, Jean-François Coste, Christophe de Champs, Laurent Andréoletti, Marie-Danièle Diebold

\section{To cite this version:}

Nicolas Lévêque, Hédia Brixi-Benmansour, Thierry Reig, Fanny Renois, Déborah Talmud, et al.. Low Frequency of Cytomegalovirus Infection during Exacerbations of Inflammatory Bowel Diseases.. Journal of Medical Virology, 2010, 82 (10), pp.1694. 10.1002/jmv.21877 . hal-00570698

\section{HAL Id: hal-00570698 https://hal.science/hal-00570698}

Submitted on 1 Mar 2011

HAL is a multi-disciplinary open access archive for the deposit and dissemination of scientific research documents, whether they are published or not. The documents may come from teaching and research institutions in France or abroad, or from public or private research centers.
L'archive ouverte pluridisciplinaire HAL, est destinée au dépôt et à la diffusion de documents scientifiques de niveau recherche, publiés ou non, émanant des établissements d'enseignement et de recherche français ou étrangers, des laboratoires publics ou privés. 


\section{Low Frequency of Cytomegalovirus Infection during Exacerbations of Inflammatory Bowel Diseases.}

\begin{tabular}{|c|c|}
\hline Journal: & Journal of Medical Virology \\
\hline Manuscript ID: & JMV-10-1790.R1 \\
\hline Wiley - Manuscript type: & Research Article \\
\hline $\begin{array}{r}\text { Date Submitted by the } \\
\text { Author: }\end{array}$ & 20-May-2010 \\
\hline Complete List of Authors: & $\begin{array}{l}\text { Lévêque, Nicolas; Faculté de médecine, université de Reims } \\
\text { Champagne Ardenne, IFR53/EA-4303; Centre Hospitalier } \\
\text { Universitaire, Unité de Virologie Médicale et Moléculaire } \\
\text { Brixi-Benmansour, Hédia; Centre Hospitalier Universitaire, Service } \\
\text { de Gastro-entérologie } \\
\text { Reig, Thierry; Centre Hospitalier Universitaire, Unité de Virologie } \\
\text { Médicale et Moléculaire } \\
\text { Renois, Fanny; Centre Hospitalier Universitaire, Unité de Virologie } \\
\text { Médicale et Moléculaire; Faculté de médecine, université de Reims } \\
\text { Champagne Ardenne, IFR53/EA-4303 } \\
\text { Talmud, Déborah; Centre Hospitalier Universitaire, Unité de } \\
\text { Virologie Médicale et Moléculaire; Faculté de médecine, université } \\
\text { de Reims Champagne Ardenne, IFR53/EA-4303 } \\
\text { Brodard, Véronique; Centre Hospitalier Universitaire, Unité de } \\
\text { Virologie Médicale et Moléculaire } \\
\text { Coste, Jean-François; Centre Hospitalier Universitaire, Unité de } \\
\text { Virologie Médicale et Moléculaire } \\
\text { De Champs, Christophe; Centre Hospitalier Universitaire, Unité de } \\
\text { Virologie Médicale et Moléculaire } \\
\text { Andréoletti, Laurent; Centre Hospitalier Universitaire, Unité de } \\
\text { Virologie Médicale et Moléculaire; Faculté de médecine, université } \\
\text { de Reims Champagne Ardenne, IFR53/EA-4303 } \\
\text { Diebold, Marie-Danièle; Centre Hospitalier Universitaire, Laboratoire } \\
\text { d'Anatomopathologie }\end{array}$ \\
\hline Keywords: & $\begin{array}{l}\text { Cytomegalovirus, inflammatory bowel diseases, exacerbation, real- } \\
\text { time quantitative PCR }\end{array}$ \\
\hline
\end{tabular}

\section{S ScholaroNE" Manuscript Central}




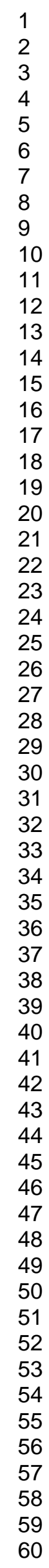

John Wiley \& Sons 


\title{
Low Frequency of Cytomegalovirus Infection during Exacerbations of Inflammatory Bowel Diseases.
}

\author{
Running title \\ Cytomegalovirus infection in Inflammatory Bowel Diseases
}

\begin{abstract}
Nicolas Lévêque ${ }^{1,2^{*}}$, Hedia Brixi-Benmansour ${ }^{3}$, Thierry $\operatorname{Reig}^{1}$, Fanny Renois $^{1,2}$, Déborah Talmud $^{1,2}$, Véronique Brodard ${ }^{1}$, Jean-François Coste ${ }^{1}$, Christophe De Champs ${ }^{1}$, Laurent Andréoletti ${ }^{1,2}$, Marie-Danièle Diebold ${ }^{4}$

${ }^{1}$ Unité de Virologie Médicale et Moléculaire, Centre Hospitalier Universitaire, Reims;

${ }^{2}$ IFR 53/EA-4303 (DAT /PPCIDH), Faculté de Médecine, Reims;

${ }^{3}$ Service de Gastro-entérologie, Centre Hospitalier Universitaire, Reims, France;

${ }^{4}$ Laboratoire d'Anatomopathologie, Centre Hospitalier Universitaire, Reims, France;
\end{abstract}

\begin{abstract}
*Corresponding author: Nicolas Lévêque, Laboratoire de Virologie, Service de Microbiologie, Hôpital Robert Debré, Avenue du Général Koenig, 51092 REIMS Cedex, France. Tel: (33) 32678 39 93; Fax: (33) 3267841 34; Electronic address: nleveque@ chu$\underline{\text { reims.fr }}$
\end{abstract}




\begin{abstract}
(248 words):
Although numerous reports have described inflammatory bowel diseases (IBD) complicated with cytomegalovirus (CMV) infection, the virus participation as an exacerbating factor remains unclear. The aim of this study was thus to clarify the clinical significance of CMV infection complicating exacerbation and to correlate CMV detection with various characteristics in IBD patients. Sixty-seven colonic biopsies obtained from 53 patients admitted for IBD exacerbation were retrospectively analyzed by real-time PCR assay. The CMV genome was detected in $7(10.4 \%)$ colonic biopsies related to 7 patients ( 3 ulcerative colitis and 4 Crohn's diseases). Among the patients with IBD studied, patients with evidence of CMV infection were older $(p=0.047$ ), were more likely male gender (relative risk [RR] 4.48; 95\% confidence interval [CI] 0.94-21.36), received corticosteroids (RR 3.2; CI 0.7913.02) or azathioprine (RR 3.17; CI 0.80-12.57) treatments, presented more extended lesions (RR for rectum-sigmoid-left colon 3.75 (0.0-69.37) and for pancolitis 2.45 (0.36-16.23)), and had a more severe disease (RR 3.3; CI 0.87-12.48) than those without CMV infection. Viral loads measured in the colonic mucosa of infected patient ranged from 5 to 236961 genome copies by microgram of total extracted DNA. No relationship was observed between the severity of the disease and the viral load level. Furthermore, CMV disappeared in 5 infected IBD patients in remission without antiviral agents. In conclusion, these results showed infrequent CMV detection in colonic biopsies of IBD patients during exacerbation leaving open the question of the relationship between CMV reactivation and the onset or the severity of IBD exacerbation.
\end{abstract}

Key-words: Cytomegalovirus, inflammatory bowel diseases, exacerbation, real-time quantitative PCR. 


\section{Introduction}

The Inflammatory Bowel Diseases (IBDs) contain mainly two types of chronic intestinal disorders: Crohn's disease and ulcerative colitis [Abraham and Cho, 2009]. They correspond to chronic inflammatory bowel disorders involving most often the ileum and the colon in Crohn's disease, and the colon and the rectum in ulcerative colitis. IBDs peak onset is in persons aged 15 to 30 [Loftus and Sandborn, 2002]. Their prevalence doubled during the past 50 years and is estimated at this day at 11 cases for 10,000 inhabitants [Shanahan and Bernstein, 2009]. Like all other immune-mediated inflammatory diseases, natural history of IBDs is characterised by periods of exacerbation and remission [Levenstein et al., 2000; Doherty and Cheifetz, 2009]. Several environmental triggers including nonsteroidal antiinflammatory drugs, antibiotics, bacterial and viral infections were identified to be responsible for the development of IBDs exacerbation [Lakatos et al., 2009; Lidar et al., 2009]. Among viral aetiologies, cytomegalovirus (CMV), a member of the herpes virus family, was reported to cause opportunistic infection in patients suffering from IBDs, usually immunosuppressed, and therefore presumably at increased risk of active infection and disease [Rowshani et al., 2005; Kandiel et al., 2006; Criscuoli et al., 2006].

CMV was associated for the first time with IBDs in 1961 when it was detected in a case of ulcerative colitis [Powell et al., 1961]. Since then, some reports have assumed a triggering role of CMV infection in the onset or the worsening of IBDs [Cooper et al., 1977; Eyre Brook and Dundas, 1986; Criscuoli et al., 2006; Kandiel et al., 2006; Orloff et al., 1989]. CMV was thus found to cause immunosuppression and to increase the severity of inflammatory diseases [Pofelski et al., 2007; Maher and Nassar, 2009]. Furthermore, CMV detection was associated with poor prognosis and steroid refractoriness [Cottone et al., 2001; Kambham et al., 2004; Maconi et al., 2005]. In most cases, CMV infections were caused by a reactivation of a latent virus due to immunosuppressive therapy; acute CMV infections were rare [Hommes et al., 2003]. Among these studies, the observed incidence of active CMV infection in IBDs patients varied widely with regard to patients'selection (ulcerative colitis or non selected patients, mild to moderate disease, severe colitis, steroid-resistant colitis, urgent colectomy for colitis) and diagnostic methods (type of sample and diagnostic method used for analysis) [Kaufman et al., 1999; Vega et al., 1999; Wada et al., 2003; Kishore et al., 2004; Takahashi and Tange, 2004; Domènech et al., 2008; Kim et al., 2010]. Incidence was thus reported to range from 0.5 to $100 \%$ and was always higher in IBDs patients than in the control groups studied [Wakefield et al., 1992; Papadakis et al., 2001]. However, despite the above- 
mentioned investigations, the strength of association between CMV infection and IBDs remains controversial [Pfau et al., 2001; Kim et al., 2010]. In fact, the relationship of superimposed CMV infection with severity and clinical outcome of IBDs is not well established, since the virus is known to replicate coincidentally due to the inflammatory disease itself and to the associated immunosuppressive therapy. Furthermore, as far as the treatment is concerned, a review of the literature does not affirm that antiviral treatment is mandatory to go into remission when CMV is detected in biopsy specimens or in peripheral blood [De Saussure et al., 2004; Matsuoka et al., 2007].

In this context, the aim of this 4-year retrospective study was to evaluate the incidence of CMV infections in a cohort of non selected IBDs patients (ulcerative colitis and Crohn's disease) using a real-time quantitative PCR assay in colonic biopsies sampled during exacerbation. It was also attempted to correlate CMV infection with various demographic, therapeutic and clinical variables in order to define a clinical index of suspicion for CMV infection in IBDs patients. The last objective was to assess the role of the CMV quantitation in biopsy specimens from the gastrointestinal mucosa for the diagnosis and the management of IBDs exacerbation by relating the viral load to clinical, histological data and to the medical treatment outcome. 


\section{Patients and Methods}

\section{Patients and samples}

All patients admitted in the gastroenterology department of the Reims University hospital between May 2005 and May 2009 for IBDs exacerbation were investigated including both outpatients and inpatients. The diagnosis of IBD was based on clinical, endoscopic, radiologic, and histologic parameters. The Lichtiger index (LI) was selected as the representative clinical index to determine the severity of the disease [Lichtiger et al., 1994]. Biopsies were obtained during colonoscopy for histological examination of inflammatory activity and routinely addressed to the virological laboratory for CMV detection. Samples were stored at $-80{ }^{\circ} \mathrm{C}$ until further processing for CMV DNA. Five millilitres venous blood were also obtained from colonic biopsies CMV positive patients to quantify CMV viremia by real-time PCR. Demographic, therapeutic and clinical profiles of all investigated patients (age, sex, IBD type, Lichtiger index, extent of the disease, severity of exacerbation and treatment) were retrospectively collected. Informed consent was obtained from each included patient. The present study was conducted by the University hospital of Reims (Champagne Ardenne, France) and was approved by the hospital's Ethics Committee.

\section{Quantitative Real-time PCR}

Five milligrams of colonic tissues were subjected to proteinase K (600 mAnson-U/ml) (Merck Novagen ${ }^{\circledR}$ ) digestion in extraction buffer containing $20 \mathrm{mM}$ Tris- $\mathrm{HCl}$ pH 8.3 (Sigma ${ }^{\circledR}$ ), and $0.5 \%$ SDS (Sigma®) 30 minutes in a water bath at $56^{\circ} \mathrm{C}$. DNA for real-time PCR assay was then extracted from the supernatant using EasyMAG ${ }^{\circledR}$ (BioMérieux, France) according to the manufacturer's instructions. The assay integrating PCR inhibitors detection was performed using an iCycler IQ ${ }^{\mathrm{TM}}$ (BioRad) as described previously [Najioullah et al., 2001]. Briefly, the oligonucleotide primers used for CMV DNA amplification were constructed to detect the late HXLF-4 transmembrane protein gene. The upstream primer was 5-ACCAACATAAGGACT TTTCACACTTTT-3 and the downstream primer was 5GAATACAGACACTTAGAGCTCGGGGT-3. The 6-carboxyfluorescein-labeled probe was 5-CTGGCCAGCACGTATCCCAACAGCA-3. The PCR conditions were incubation at $95^{\circ} \mathrm{C}$ for 10 minutes, 45 cycles of $95^{\circ} \mathrm{C}$ for 15 seconds, followed by incubation at $60^{\circ} \mathrm{C}$ for 15 seconds and $72^{\circ} \mathrm{C}$ for 40 seconds. 
Total DNA was quantified at 260/280 nm using a spectrophotometer. CMV viral load levels were then expressed as the number of CMV DNA copies by microgram $(\mu \mathrm{g})$ of extracted DNA.

\section{Statistical Analysis}

Statistical analysis to determine the characteristics associated with CMV infection in IBDs patients was conducted by utilizing the Chi-squared test or two-tailed Fisher exact test to compare qualitative variables, and Student's t-test for quantitative variables. These analyses were carried out with SPSS 11.0 program (SPSS, Paris, France). A $p$ value $<0.05$ was considered statistically significant. The $95 \%$ confidence intervals (95\% CI) were calculated for the relative risk using Taylor series confidence intervals with Epi Info version 6 software (Center for Disease Control USA). 


\section{RESULTS}

\section{Demographic and clinical parameters of investigated patients with exacerbate IBD}

From May 2005 to May 2009, 53 patients were admitted in the Gastroenterology department of the Reims university hospital for IBD exacerbation. Forty-two patients (79.2\%) presented a single event of exacerbation while $9(17 \%)$ had two, one had three and one $(1.9 \%)$ had 4. Sixty-seven colonic biopsies, corresponding each to one exacerbation phase, were thus collected from the 53 patients during the 4-year study. Among the 53 included patients, 20 (37.7\%) had ulcerative colitis (sex-ratio M/F: 0.7) while 33 (62.3\%) had Crohn's disease (sexratio $\mathrm{M} / \mathrm{F}$ : 0.45). At the time of their assessment in the study, the median age of ulcerative colitis patients was $40 \pm 14.6$, while it was $37 \pm 16.1$ in Crohn's disease patients. In addition, mean duration of IBD in these patients was 9.8 years. As defined by Lichtiger index, 42 $(62.7 \%)$ selected patients had clinically moderate to severe IBD at time of exacerbation. IBD described pancolitis in $25.9 \%$. Eight patients (14.8\%) were resistant to steroids while 12 (22\%) were steroid-dependent. Thirteen (24\%) presented with a history of colectomy. All the demographic, therapeutic and clinical characteristics of the IBD patients are shown in table 1.

\section{Prevalence of active CMV infection during IBD exacerbation}

The CMV genome was found in the colonic mucosa by PCR in $7(10.4 \%)$ of the 67 colonic biopsies corresponding to 7 patients (13.2\%): $3(15 \%)$ of those with ulcerative colitis and 4 (12.1\%) of those with Crohn's disease. CMV infection incidence was not statistically significant between the two types of IBD.

\section{Factors associated with CMV infection}

Table 2 summarizes the association of various clinical characteristics with or without CMV infection in IBDs patients. Due to the small number of CMV infection, statistical analysis was conducted on overall IBDs patients with no distinction between ulcerative colitis and Crohn's disease. On statistical analysis patients with evidence of CMV infection were older ( $p=$ 0.047), were more often male gender (relative risk [RR] 4.48; 95\% confidence interval [CI] 0.94-21.36), had been more often on corticosteroids (RR 3.2; CI 0.79-13.02) or azathioprine (RR 3.17; CI 0.80-12.57) treatments than those without CMV infection. Furthermore, infected patients presented more extended lesions (RR for rectum-sigmoid-left colon 3.75 (0.0-69.37) and for pancolitis 2.45 (0.36-16.23)), and had a more severe disease (RR 3.3; CI 0.87-12.48). Interestingly, female gender, IBD type, smoking, administration of biologics, dependence or 
resistance to corticosteroids and requirement for surgical treatment, were not statistically associated with CMV detection in the colonic tissue (table 2).

\section{Relationship between viral load in colonic biopsies and clinical management and outcome of exacerbation}

CMV DNA was detected and quantified in 7 biopsy specimens corresponding to 7 IBD exacerbations (table 3). Furthermore, one patient (P48) underwent a second endoscopy 2 weeks after initial CMV detection for virological and histological monitoring, which was thus not considered as a second IBD flare. Viral load was then correlated to the treatment, in particular the administration of antiviral therapy, and to the clinical outcome of the IBD exacerbation. In the positive studied biopsies, CMV DNA load ranged from 5 to 236961 genome copies/ $\mu \mathrm{g}$ of total extracted DNA with a median viral load of 37433 copies (table 3 ). Among the $7 \mathrm{CMV}$ positive patients, 6 did not receive antiviral therapy. In 5 patients, the course of the disease was significantly improved by intensifying immunosuppressive therapy resulting in the decrease of abdominal pain, colitis lesions and diarrhea. For the last patient without antiviral therapy, the patient P1 who presented Crohn's disease, the IBD evolution required surgical treatment (table 3).

CMV detection in colonic biopsy was associated with the administration of intravenous ganciclovir followed by oral valganciclovir for only one patient, the patient P48 (table 3). Antiviral treatment was administrated because of the severity of the clinical symptoms. Rapid and significant decrease of viral load was observed both in the colonic biopsy and in the blood samples, since CMV DNA became undetectable in the patient's plasma 3 weeks after the beginning of the antiviral treatment (figure 1). At the same time, immunosuppressive therapy was also reinforced by the association of intravenous corticosteroids and anti-TNF alpha therapy to the previous azathioprine and mesalamine treatment. The course of the disease improved rapidly, since the Lichtiger score decreased from 12 at time of admission to 1 one month later. 


\section{DISCUSSION}

In this study, 67 colonic biopsies sampled from 53 patients suffering from exacerbation of IBD were analyzed retrospectively. CMV was detected in 7 biopsies corresponding to 7 exacerbations that occurred in 7 different patients establishing a prevalence of CMV infection at $10.4 \%$. The prevalence rates of CMV infection among IBDs populations reported previously ranged from $0.5 \%$ to $72 \%$ [Wakefield et al., 1992; Papadakis et al., 2001]. Studies including patients presenting acute severe colitis or steroid-refractory colitis described the highest CMV prevalence [Cottone et al., 2001; Criscuoli et al., 2004; Minami et al., 2007; Yoshino et al., 2007; Maher et al., 2008]. Only 3 studies could be legitimately compared with the present work. These studies have determined CMV prevalence by PCR assays in colonic biopsies obtained from non selected IBD patients. In 1992, Wakefield et al. highlighted the prevalence of the CMV infection of $72 \%$, whereas Kishore et al. in 2004 and Dimitroulia et al. in 2006 described the prevalence of $16 \%$ and 33\%, respectively [Wakefield et al., 1992; Kishore et al., 2004. Dimitroulia et al., 2006]. This prevalence, variable from one study to another, was significantly higher than the one reported here. The most obvious difference holds in the technique of PCR employed, nested for Wakefield, standard for Kishore and Dimitroulia or real-time PCR assay in the present study. Considering the high sensitivity of the previously published real-time PCR assay used in this work, lower CMV prevalence may be due to the over-representation of Crohn's disease patients (62.3\% of the IBD population studied) [Najioullah et al., 2001]. Prior reports showed a higher incidence of CMV in ulcerative colitis patients compared to Crohn's disease patients [Loftus et al., 1994; Vega et al., 1999; Cottone et al., 2001; Kim et al., 2010]. Furthermore, the therapeutic protocols, some of them at higher risk of causing CMV reactivation, and the percentage of seropositive patients for CMV among IBD studied patients could vary from a hospital to another and thus generate differences in viral infection prevalence.

Demographic and clinical characteristics of IBDs patients presenting or not CMV infection were then compared to try to determine specific profile and predisposing factors to viral infection (table 2). Unfortunately, in spite of a 4-year recruitment, only a small number of CMV positive biopsies were obtained limiting thus the significance of the statistical analysis of collected data. Because of the small number of infected patients, the remaining analysis was conducted on all the IBDs population with no distinction between ulcerative colitis and Crohn's disease patients. Several risk factors of developing CMV infection were this way identified (table 2). The first characteristic was that patients with CMV infection 
were significantly older. The second risk factor was a treatment by corticosteroids or azathioprine. This result was in agreement with the data reported previously demonstrating a statistically significant association between azathioprine or a high-dose systemic corticosteroids therapy and the detection of CMV in the colonic biopsies of IBDs patients [Cottone et al., 2001; Wada et al., 2003; Yoshino et al., 2007; Domènech et al., 2008]. Domènech detected the CMV only among corticosteroid-refractory ulcerative colitis patients treated for 7 to 10 days with a high-dose systemic corticosteroids therapy. The prevalence observed was 32\% [Domènech et al., 2008]. More generally, high CMV detection rates were logically associated with the administration of intensive immunosuppressive therapies. Yoshino detected the genome of CMV in 57\% of the colonic biopsies (17 biopsies out of 30) of patients suffering from ulcerative colitis refractory to immunosuppressive therapies, including corticosteroids and immunomodulators [Yoshino et al., 2007]. It is interesting to note that the present study confirmed that anti-Tumor Necrosis Factor (TNF) alpha therapy, known to be highly immunosuppressive, did not seem to be significantly associated with CMV infection [D'Ovidio et al., 2008]. The continuation of this study should allow to improve the knowledge of clinical characteristics associated to CMV infection and of factors predisposing to CMV infection in IBDs patients.

CMV viral loads in colonic biopsies were then determined using a real-time PCR assay and normalized as the number of CMV DNA copies by $\mu \mathrm{g}$ of extracted DNA. Although real-time PCR assay was used previously for detection of CMV infection in patients with IBDs, this study is the first to define the level of CMV replication in the intestine tissue [Matsuoka et al., 2007; Minami et al., 2007; Yoshino et al., 2007]. The value of viral quantitation, in contrast to the qualitative PCR assays, is to define the level of replication of the virus and then to try to link it to the severity of the disease or to give it a prognostic value. Furthermore, in case of antiviral treatment the quantitative PCR can also allow to follow the therapeutic effectiveness through the decrease of the viral load [Baldanti et al., 2008]. In this report, the viral loads measured among IBDs CMV positive patients ranged from 5 to 236961 genome copies/ $\mu \mathrm{g}$ of total extracted DNA. Interestingly, the CMV replication level was not related to the severity of the exacerbation, since viral loads at 5 and 236961 copies respectively detected in the P17 and P27 patients were associated with moderate exacerbation, whereas viral load at 1834 in patient P1 corresponded to severe disease and poor outcome (table 3). A limitation of this aspect in the present study was again the small number of positive biopsies to conclude on the basis of viral quantitation for the prognosis of IBD exacerbation evolution. Sampling error should also be considered, since CMV replication 
within the colonic mucosa could be focal. Therefore, the possibility of underestimating CMV viral load in case of severe disease cannot be entirely excluded.

Despite the association between CMV and the extent and the severity of the disease suggested by the statistical analyses, the results obtained in this study did not provide a clear evidence of the pathogenicity of CMV in IBDs exacerbation. Five of the 7 CMV positive patients went into remission by reinforcement of immunosuppressive therapies without administration of antiviral treatment (table 3). Clinical improvement in spite of the lack of antiviral medication was reported previously in many studies [De Saussure et al., 2004; Matsuoka et al., 2007; Kim et al., 2010]. In this series, only one patient among the 7 IBD patients presenting colonic biopsy positive for the CMV received ganciclovir. Clinical improvement, consisting in the decrease of the Lichtiger score from 12 to 1 within 3 weeks, was then observed along with the decrease of the viral load in the plasma as well as in the colonic mucosa. However, clinical improvement could not be only related to the antiviral treatment responsible for CMV viral load decrease, since the immunosuppressive therapy was introduced concomitantly. The good correlation noticed between plasma and colonic mucosa viral loads was an interesting diagnostic data to consider a possible virological monitoring of the patient by examination of blood samples instead of colonic biopsies.

In summary, the aim of this 4-year retrospective study was to clarify the clinical significance of CMV infection complicating IBDs exacerbation. The results showed infrequent CMV detection in colonic biopsies of IBDs patients without any correlation between the severity of the disease and the viral load levels in the colonic mucosa. Furthermore, CMV disappeared in most infected IBDs patients without antiviral treatment. In conclusion, the relationship between CMV reactivation and the onset or the severity of IBDs exacerbation remains debatable. 
Table 1. Demographic, therapeutic and clinical characteristics of IBD investigated patients at time of exacerbation. Numbers in parentheses indicate percentage. Ranges are indicated in brackets.

\begin{tabular}{|c|c|}
\hline Characteristic & Overall IBD patients \\
\hline Median age (years) & $38.5[16 ; 81]$ \\
\hline Duration of disease (years) & $9.8[0.5 ; 21.8]$ \\
\hline Male & $23(43.4)$ \\
\hline Female & $30(56.6)$ \\
\hline Crohn's disease & $33(62.3)$ \\
\hline Ulcerative colitis & $20(37.7)$ \\
\hline Smoker & $10(23.8)$ \\
\hline \multicolumn{2}{|l|}{ Extent of disease } \\
\hline Rectum & $16(29.6)$ \\
\hline Sigmoid & $6(11.1)$ \\
\hline 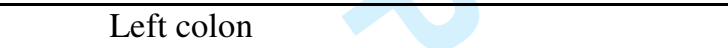 & $4(7.4)$ \\
\hline Rectum Sigmoid & $6(11.1)$ \\
\hline Rectum Sigmoid Left colon & $4(7.4)$ \\
\hline Colitis & $4(7.4)$ \\
\hline Pancolitis & $14(25.9)$ \\
\hline \multicolumn{2}{|l|}{ Clinical severity of the disease } \\
\hline 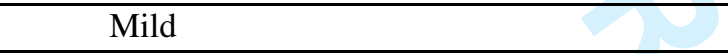 & $12(22.2)$ \\
\hline Moderate & $32(59.3)$ \\
\hline Severe & $10(18.5)$ \\
\hline \multicolumn{2}{|c|}{ Medications at time of the assessment in the study } \\
\hline None & $8(14.8)$ \\
\hline Mesalamine & $24(44.4)$ \\
\hline Corticosteroids & $7(13.0)$ \\
\hline Azathioprine & $16(29.6)$ \\
\hline Methotrexate & $6(11.1)$ \\
\hline Anti-TNF $\alpha$ & $11(20.4)$ \\
\hline Corticosteroid-dependant & $12(22.2)$ \\
\hline Corticosteroid-resistant & $8(14.8)$ \\
\hline History of colectomy & $11(20.4)$ \\
\hline
\end{tabular}


Table 2. Demographic, therapeutic and clinical characteristics of IBD patients with or without detection of CMV genome in their intestinal tissue samples. Numbers in parentheses indicate percentage. ND, not done. CI, confidence interval.

\begin{tabular}{|c|c|c|c|}
\hline Characteristics & CMV positive & CMV negative & $\begin{array}{c}\text { Relative risk } \\
{[95 \% \mathrm{CI}]} \\
\end{array}$ \\
\hline Age $>38$ years old & $5(71.4)$ & $29(48.3)$ & $2.43[0.51-11.64]$ \\
\hline Male & $5(71.4)$ & $19(39.1)$ & $4.48[0.94-21.36]$ \\
\hline Crohn's disease & $4(57.1)$ & $38(63)$ & $0.79[0.19-3.26]$ \\
\hline Ulcerative colitis & $3(42.9)$ & $22(37)$ & $1.26[0.31-5.18]$ \\
\hline Smoker & $1(14.3)$ & $11(22.0)$ & $0.58[0.08-4.39]$ \\
\hline Extent of disease & & & \\
\hline Rectum & $1(14.3)$ & $15(31.9)$ & $0.4[0.05-3.03]$ \\
\hline Sigmoid & $0(0)$ & $6(12.8)$ & ND \\
\hline Left colon & $1(14.3)$ & $3(6.4)$ & $2.08[0.33-13.33]$ \\
\hline Rectum Sigmoid & $1(14.3)$ & $5(10.6)$ & $1.33[0.19-9.27]$ \\
\hline Rectum Sigmoid Left colon & $1(14.3)$ & $2(4.3)$ & $2.83[0.48-16.60]$ \\
\hline Colitis & $0(0)$ & $4(8.5)$ & ND \\
\hline Pancolitis & $3(42.9)$ & $11(23.4)$ & $2.14[0.55-8.41]$ \\
\hline Clinical severity of the disease & $x^{2}$ & & \\
\hline Mild & $1(14.3)$ & $11(23.4)$ & $0.58[0.08-4.39]$ \\
\hline Moderate & $3(42.9)$ & $29(61.7)$ & $0.52[0.13-2.08]$ \\
\hline Severe & $3(42.9)$ & $7(14.9)$ & $3.3[0.87-12.48]$ \\
\hline Medications at time of the assessment in the study & 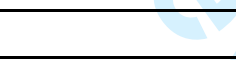 & & \\
\hline None & $1(14.3)$ & $8(17.0)$ & $0.83[0.11-6.11]$ \\
\hline Mesalamine & $3(42.9)$ & $19(40.4)$ & $1.09[0.27-4.4]$ \\
\hline Corticosteroids & $2(28.6)$ & $4(8.5)$ & $3.2[0.79-13.02]$ \\
\hline Azathioprine & $4(57.1)$ & $12(25.5)$ & $3.17[0.80-12.57]$ \\
\hline Methotrexate & $0(0)$ & $6(12.8)$ & $\mathrm{ND}$ \\
\hline Anti-TNF $\alpha$ & $0(0)$ & $11(23.4)$ & ND \\
\hline Corticosteroid-dependant & $1(14.3)$ & $11(23.4)$ & $0.58[0.08-4.39]$ \\
\hline Corticosteroid-resistant & $0(0)$ & $8(17.4)$ & ND \\
\hline History of colectomy & $2(28.6)$ & $11(23.4)$ & $1.26[0.28-5.75]$ \\
\hline
\end{tabular}


1

3

4

5

6

7

8

9

10

11

12

13

14

15

16

17

18

19

20

21

22

23

Table 3. Description of the relationship between CMV viral load in colonic biopsies with the severity of the disease, the use of immunosuppressive and antiviral therapies and the outcome of the exacerbation.

\begin{tabular}{|c|c|c|c|c|c|c|}
\hline Patients & $\begin{array}{l}\text { CMV viral } \\
\text { load } \\
\text { (copies by } \mu \text { g of } \\
\text { total DNA) }\end{array}$ & $\begin{array}{l}\text { Severity of } \\
\text { the disease }\end{array}$ & $\begin{array}{l}\text { Immunosuppressive } \\
\text { therapy at onset of } \\
\text { exacerbation }\end{array}$ & $\begin{array}{l}\text { Immunosuppressive } \\
\text { therapy at remission of } \\
\text { exacerbation }\end{array}$ & $\begin{array}{l}\text { Antiviral } \\
\text { treatment }\end{array}$ & $\begin{array}{c}\text { Exacerbation } \\
\text { outcome }\end{array}$ \\
\hline P 1 & 1834 & Severe & AZA & AZA, CS, MES & None & $\begin{array}{l}\text { Poor with } \\
\text { colectomy }\end{array}$ \\
\hline P 15 & 4677 & Severe & $\mathrm{AZA}, \mathrm{CS}$ & $\mathrm{AZA}, \mathrm{CS}$ & None & Remission \\
\hline P 17 & 5 & Moderate & MES & CS, MES & None & Remission \\
\hline P 27 & 236961 & Moderate & AZA & AZA, CS & None & Remission \\
\hline P 34 & 145 & Moderate & MES & MES & None & Remission \\
\hline $\mathrm{P} 45$ & 845 & Mild & None & $\mathrm{CS}$ & None & Remission \\
\hline P 48 B 1 & 51812 & Severe & AZA, CS, MES & \multirow{2}{*}{$\begin{array}{c}\text { Anti-TNF } \alpha, \text { AZA, CS, } \\
\text { MES }\end{array}$} & \multirow{2}{*}{$\begin{array}{c}I V \\
\text { ganciclovir }\end{array}$} & \multirow{2}{*}{ Remission } \\
\hline P 48 B2 & 3189 & Moderate & IV CS, AZA, MES & & & \\
\hline
\end{tabular}

AZA : Azathioprine ; CS : corticosteroids ; MES : Mesalamine; $I V$ : intravenous 


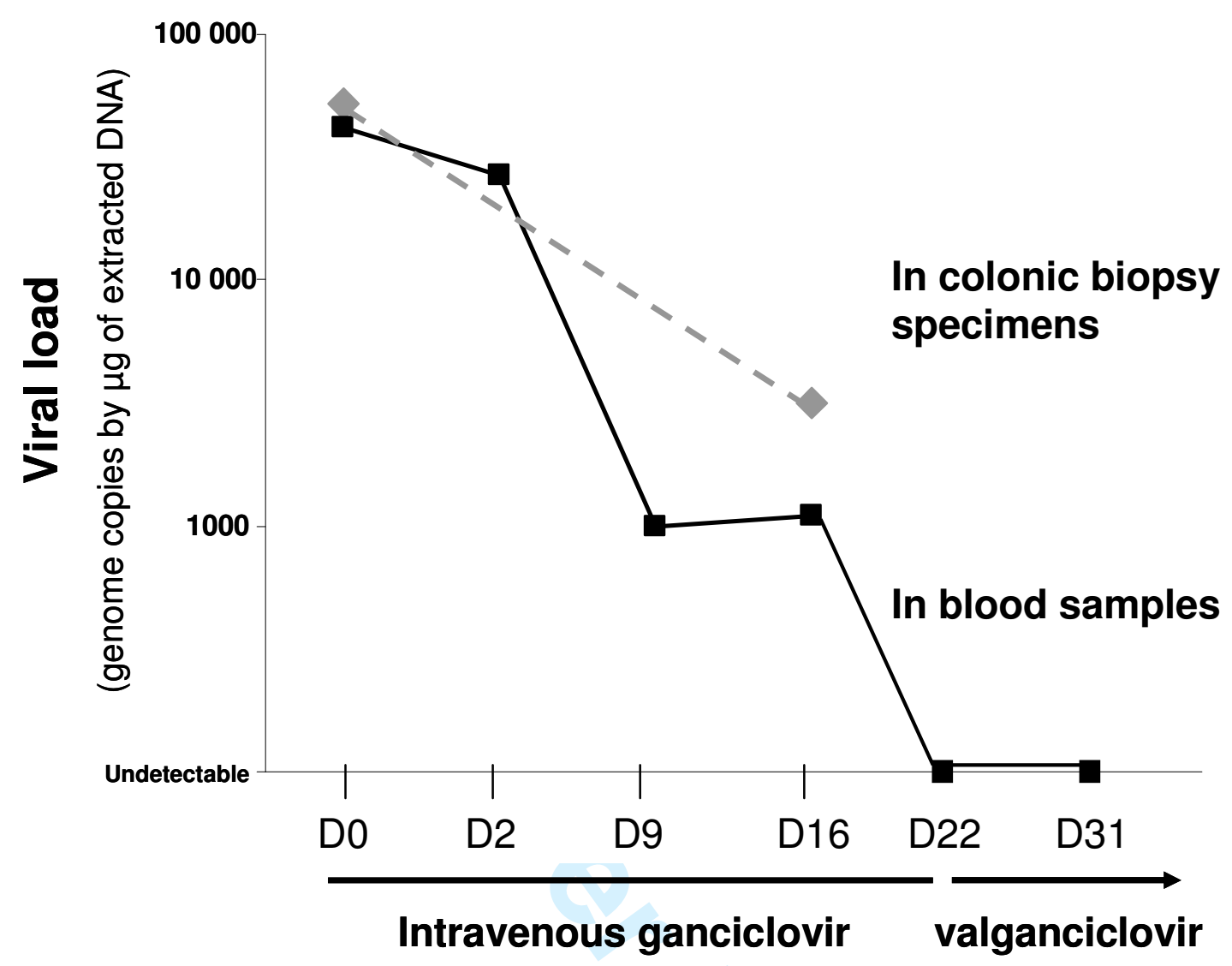

Figure 1. Comparative monitoring of CMV DNA load levels in colonic biopsy specimens and in blood samples in patient P48 after applying two successive antiviral therapies. 


\section{Acknowledgments}

The authors thank Lysiane Bourdaire, Harmony Lapie, Petra Hutig and Dorine Lebrun for their technical help during this study. They also thank Ms Jocelyne Wuibout to have kindly reviewed the English of this paper.

\section{Conflict of interest statement}

None of the authors have conflict of interest or funding source to declare in connection with this study. 


\section{References}

Abraham C, Cho JH. 2009. Inflammatory bowel disease. N Engl J Med 361:2066-2078.

Baldanti F, Lilleri D, Gerna G. 2008. Human cytomegalovirus load measurement and its applications for pre-emptive therapy in patients undergoing hematopoietic stem cell transplantation. Hematol Oncol 26:123-130.

Cooper HS, Raffensperger EC, Jonas L, Fitts WT Jr. 1977. Cytomegalovirus inclusions in patients with ulcerative colitis and toxic dilation requiring colonic resection. Gastroenterology 72:1253-1256.

Cottone M, Pietrosi G, Martorana G, Casà A, Pecoraro G, Oliva L, Orlando A, Rosselli M, Rizzo A, Pagliaro L. 2001. Prevalence of cytomegalovirus infection in severe refractory ulcerative and Crohn's colitis. Am J Gastroenterol 96:773-775.

Criscuoli V, Casà A, Orlando A, Pecoraro G, Oliva L, Traina M, Rizzo A, Cottone M. Severe acute colitis associated with CMV: a prevalence study. Dig Liver Dis 2004 36:818-820.

Criscuoli V, Rizzuto MR, Cottone M. 2006. Cytomegalovirus and inflammatory bowel disease: is there a link? World J Gastroenterol 12:4813-4818.

De Saussure P, Lavergne-Slove A, Mazeron MC, Alain S, Matulcerative colitishansky C, Bouhnik Y. 2004. A prospective assessment of cytomegalovirus infection in active inflammatory bowel disease. Aliment Pharmacol Ther 20:1323-1327.

Dimitroulia E, Spanakis N, Konstantinidou AE, Legakis NJ, Tsakris A. 2006. Frequent detection of cytomegalovirus in the intestine of patients with inflammatory bowel disease. Inflamm Bowel Dis 12:879-884.

Doherty GA, Cheifetz AS. 2009. Management of acute severe ulcerative colitis. Expert Rev Gastroenterol Hepatol 3:395-405.

Domènech E, Vega R, Ojanguren I, Hernández A, Garcia-Planella E, Bernal I, Rosinach M, Boix J, Cabré E, Gassull MA. 2008. Cytomegalovirus infection in ulcerative colitis: a prospective, comparative study on prevalence and diagnostic strategy. Inflamm Bowel Dis 14:1373-1379.

D'Ovidio V, Vernia P, Gentile G, Capobianchi A, Marcheggiano A, Viscido A, Martino P, Caprilli R. 2008. Cytomegalovirus infection in inflammatory bowel disease patients undergoing anti-TNFalpha therapy. J Clin Virol 43:180-183.

Eyre Brook IA, Dundas S. 1986. Incidence and clinical significance of colonic cytomegalovirus infection in idiopathic inflammatory bowel disease requiring colectomy. Gut 27:1419-1425. 
Hommes DW, Sterringa G, van Deventer SJ, Tytgat GN, Weel J. 2004. The pathogenicity of cytomegalovirus in inflammatory bowel disease: a systematic review and evidencebased recommendations for future research. Inflamm Bowel Dis 10:245-250.

Kambham N, Vij R, Cartwright CA, Longacre T. 2004. Cytomegalovirus infection in steroidrefractory ulcerative colitis: a case-control study. Am J Surg Pathol 28:365-373.

Kandiel A, Lashner B. 2006. Cytomegalovirus colitis complicating inflammatory bowel disease. Am J Gastroenterol 101:2857-2865.

Kaufman HS, Kahn AC, Iacobuzio-Donahue C, Talamini MA, Lillemoe KD, Hamilton SR. 1999. Cytomegaloviral enterocolitis: clinical associations and outcome. Dis Colon Rectum 42:24-30.

Kim JJ, Simpson N, Klipfel N, Debose R, Barr N, Laine L. 2010. Cytomegalovirus Infection in Patients with Active Inflammatory Bowel Disease. Dig Dis Sci [Epub ahead of print].

Kishore J, Ghoshal U, Ghoshal ULCERATIVE COLITIS, Krishnani N, Kumar S, Singh M, Ayyagari A. 2004. Infection with cytomegalovirus in patients with inflammatory bowel disease: prevalence, clinical significance and outcome. J Med Microbiol 53:1155-1160.

Lakatos PL. 2009. Environmental factors affecting inflammatory bowel disease: have we made progress? Dig Dis 27:215-225.

Levenstein S, Prantera C, Varvo V, Scribano ML, Andreoli A, Luzi C, Arcà M, Berto E, Milite G, Marcheggiano A. 2000. Stress and exacerbation in ulcerative colitis: a prospective study of patients enrolled in remission. Am J Gastroenterol 95:1213-1220.

Lichtiger S, Present DH, Kornbluth A, Gelernt I, Bauer J, Galler G, Michelassi F, Hanauer S. 1994. Cyclosporine in severe ulcerative colitis refractory to steroid therapy. N Engl J Med 330:1841-1845.

Lidar M, Langevitz P, Shoenfeld Y. 2009. The role of infection in inflammatory bowel disease: initiation, exacerbation and protection. Isr Med Assoc J 11:558-63.

Loftus EV Jr, Alexander GL, Carpenter HA. 1994. Cytomegalovirus as an exacerbating factor in ulcerative colitis. J Clin Gastroenterol 19:306-309.

Maconi G, Colombo E, Zerbi P, Sampietro GM, Fociani P, Bosani M, Cassinotti A, Casini V, Russo A, Ardizzone S, Porta M, Bianchi Porro G. 2005. Prevalence, detection rate and outcome of cytomegalovirus infection in ulcerative colitis patients requiring colonic resection. Dig Liver Dis 37:418-423.

Maher MM, Nassar MI. 2009. Acute cytomegalovirus infection is a risk factor in refractory and complicated inflammatory bowel disease. Dig Dis Sci 54:2456-2462. 
Matsuoka K, Iwao Y, Mori T, Sakuraba A, Yajima T, Hisamatsu T, Okamoto S, Morohoshi Y, Izumiya M, Ichikawa H, Sato T, Inoue N, Ogata H, Hibi T. 2007. Cytomegalovirus is frequently reactivated and disappears without antiviral agents in ulcerative colitis patients. Am J Gastroenterol 102:331-337.

Minami M, Ohta M, Ohkura T, Ando T, Ohmiya N, Niwa Y, Goto H. 2007. Cytomegalovirus infection in severe ulcerative colitis patients undergoing continuous intravenous cyclosporine treatment in Japan. World J Gastroenterol 13:754-760.

Najioullah F, Thouvenot D, Lina B. 2001. Development of a real-time PCR procedure including an internal control for the measurement of HCMV viral load. J Virol Methods 92:55-64.

Orloff JJ, Saito R, Lasky S, Dave H. 1989. Toxic megacolon in cytomegalovirus colitis. Am J Gastroenterol 84:794-797.

Papadakis KA, Tung JK, Binder SW, Kam LY, Abreu MT, Targan SR, Vasiliauskas EA. 2001. Outcome of cytomegalovirus infections in patients with inflammatory bowel disease. Am J Gastroenterol 96:2137-2142.

Pfau P, Kochman ML, Furth EE, Lichtenstein GR. 2001. Cytomegalovirus colitis complicating ulcerative colitis in the steroid-naive patient. Am J Gastroenterol 96:895899.

Podolsky DK. 2002. Inflammatory bowel disease. N Engl J Med 347:417-429.

Pofelski J, Heluwaert F, Roblin X, Morand P, Gratacap B, Germain E, Brion JP, Salon C, Bonaz B. 2007. Cytomegalovirus and cryptogenic inflammatory bowel disease. Gastroenterol Clin Biol 31:292-296.

Powell RD, Warner NE, Levine RS, Kirsner JB. 1961. Cytomegalic inclusion disease and ulcerative colitis; report of a case in a young adult. Am J Med 30:334-340.

Rowshani AT, Bemelman FJ, van Leeuwen EM, van Lier RA, ten Berge IJ. 2005. Clinical and immunologic aspects of cytomegalovirus infection in solid organ transplant recipients. Transplantation 79:381-386.

Shanahan F, Bernstein CN. 2009. The evolving epidemiology of inflammatory bowel disease. Curr Opin Gastroenterol 25:301-305.

Takahashi Y, Tange T. 2004. Prevalence of cytomegalovirus infection in inflammatory bowel disease patients. Dis Colon Rectum 47: 722-726.

Vega R, Bertrán X, Menacho M, Domènech E, Moreno de Vega V, Hombrados M, Cabré E, Ojanguren I, Gassull MA. 1999. Cytomegalovirus infection in patients with inflammatory bowel disease. Am J Gastroenterol 94:1053-1056. 
Wada Y, Matsui T, Matake H, Sakurai T, Yamamoto J, Kikulcerative colitishi Y, Yorioka M, Tsuda S, Yao T, Yao S, Haraoka S, Iwashita A. 2003. Intractable ulcerative colitis caused by cytomegalovirus infection: a prospective study on prevalence, diagnosis, and treatment. Dis Colon Rectum 46:S59-65.

Wakefield AJ, Fox JD, Sawyerr AM, Taylor JE, Sweenie CH, Smith M, Emery VC, Hudson M, Tedder RS, Pounder RE. 1992. Detection of herpesvirus DNA in the large intestine of patients with ulcerative colitis and Crohn's disease using the nested polymerase chain reaction. J Med Virol 38:183-190.

Yoshino T, Nakase H, Ueno S, Uza N, Inoue S, Mikami S, Matsuura M, Ohmori K, Sakurai T, Nagayama S, Hasegawa S, Sakai Y, Chiba T. 2007. Usefulness of quantitative realtime PCR assay for early detection of cytomegalovirus infection in patients with ulcerative colitis refractory to immunosuppressive therapies. Inflamm Bowel Dis $13: 1516-1521$. 